\title{
Archival Sources for Legal Biography at The Institute of Advanced Legal Studies
}

\author{
Author \\ Elizabeth Dawson \\ Archivist \\ Institute of Advanced Legal Studies \\ Charles Clore House, 17 Russell Square, London WC1 5DR
}

\begin{abstract}
The article outlines archival sources for legal biography held at the Institute of Advanced Legal Studies, focussing on primary sources of information on individuals, including the Law Society and Bar Examination results.

It also summarises additional sources which provide biographical information on legal practitioners and scholars eg. the archives of The Society of Legal Scholars and the Council of Legal Education, IALS institutional archives, The Bar Council, The International Law Association and academic membership associations.
\end{abstract}

The article also provides guidance to researchers on using the IALS Archive, and advice on using related external archival sources.

\section{Biographical summary}

Elizabeth Dawson is currently archivist (part time) at the Institute of Advanced Legal Studies and she has extensive experience of Archives and Records Management, having worked at The Public Record Office (now the National Archives), The National Maritime Museum, The Inner London Education Authority and BP Exploration. She also works as an archive management consultant, specialising in the UK charitable, cultural, heritage, educational, public and not for profit sectors.

Word count 3194 


\section{Introduction}

This article describes the main sources for legal biography held at the Institute of Advanced Legal Studies (IALS) Archive, focussing on major primary sources including the Law Society and Bar Examination results, but also on other important additional sources amongst the history of legal education which may provide useful information on the careers and activities of legal practitioners and scholars, including the archives of The Council of Legal Education and the Society of Legal Scholars.

Sources within the institutional archives of IALS will also be considered, together with additional collections including the archives of The Bar Council and The International Law Association.

The article will also provide guidance to researchers on using the IALS Archive, together with advice on some external sources which may be useful for tracing dates, locations and identifying relevant individuals before researching at IALS e.g. genealogical sources, newspaper reports, directories and other on line material.

\section{Starting research at IALS}

What preliminary information might a researcher need when starting research at IALS? This will of course depend on what other information the researcher has already acquired, and also on its accuracy: some basic details eg names, dates, location, profession, are essential, and most researchers are confident that they have this information already, but in some cases, this can prove to be less than reliable, depending on the original source.

Assumptions concerning dates are frequently made, particularly in relation to admission and examinations, and the reality often proves otherwise, particularly if the candidate had had to re-sit examinations. Even names can lead to ambiguity: the use of middle names, extra initials, alternative spellings can sometimes cause confusion and may need to be checked elsewhere. Some additional sources for research are discussed at the end of this article, and may prove helpful in avoiding confusion before starting your research at IALS.

\section{Overview of archival sources at IALS}

The IALS Archives collection has four main strands, all of which may be useful in tracing the careers of individuals involved in the all aspects of the legal profession, whether law practitioners, academics or law librarians.

The largest strand is that of the Records of Legal Education Archive (RLEA), which was developed as the result of a major project during 1994 - 1998 which aimed to identify and preserve the records of organisations and individuals involved in Legal Education, including both academic and professional bodies. The resulting archive collection includes those of the Council of Legal Education, The Society of Legal Scholars (formerly the Society of Public Teachers of the Law), The Commonwealth Legal Education Association, The Association of Law Teachers and The International Law Association. The RLEA Archive now includes several series of Law Society Examination results which were deposited at IALS in 2007. 
IALS also maintains its own institutional archive ranging from the original proposal to develop a post graduate institute and library, (with an original 1948 prospectus) to more recent developments and we also hold important collections relating to Law Librarianship, including the archives of The International Association of Law Libraries (IALL); The British and Irish Association of Law Librarians (BIALL).

The most recent archive collection deposited at IALS is that of the General Council of the Bar, dealing with matters of policy and professional practice of the Bar. The collection has only recently been appraised and catalogued, and the final catalogue will shortly be made available on the IALS website.

Some of these collections include primary sources of information on individuals, while others include useful material produced by or mentioning the activities of individuals in their professional context.

\section{Primary sources for legal biography}

The most immediately relevant and useful primary sources of detailed information on individuals can be found in the series of Bar Examinations and Law Society examination results, which date from the mid nineteenth century onwards.

\section{Bar Examination records (series CLE 11) 1861 - 1957}

What might a researcher hope to find within these records? The contents and level of detail varies according to the period concerned, and there is some variation and development of the system of recording examinations, but at the very least one will be able to find the names of all candidates, their marks for individual subjects, a note of the maximum possible marks and the date and term of the examination. Other information can include the number of terms kept, the Inn of Court and information about prizes awarded. The earlier material is in manuscript but is mainly typescript post 1920.

The whole series consists of only 24 volumes. The contents of each volume are arranged by term date, and the progress of individuals can therefore be traced chronologically. Researchers should note, however, that there is no central index to these results, but each volume contains an integral contemporary $A-Z$ index of names (although these are not always in strict alphabetical order within each letter!) giving page references.

A small but potentially interesting volume relating to individuals should also be noted: CLE 17 / 1: Register of Attendance at periodic lectures. This handwritten attendance register contains signatures of students attending occasional specialist subject lectures between 1902 and 1922, comprising a rare survival of an apparently ephemeral record, but which has recently been used by an academic researcher, who was able to find early evidence of the specialist legal interests of a number of bar students. 
Very few examples of examination questions have survived in the archive (see CLE / 39, but a complete set of examination question papers is available at Lincoln's Inn Library.

\section{Law Society Examination records 1836 - 1984 (series LSOC 1 - 14)}

This collection, which is more extensive than Bar Council examination results, consists of 412 volumes and 51 files, reflecting the lengthier training process and larger number of candidates. Overall dates vary according to level of examination but the earliest extant is the 1836 list of candidates for final examination. There is no central index, but each volume is individually indexed in a similar manner to the CLE examination records. As with the Bar Examinations, earlier material is in manuscript with later entries in typescript.

There are a number of series of records, with some overlap of information between them. The system of recording examinations developed and changed at various times, and the information given and level of detail varies according to date and researchers should refer to individual series catalogues for fuller details, but basic information will include: name of candidate; examinations taken (subject, level); dates of examination; results (and marks out of a possible maximum).

Additional information, depending on date, may also include: age; home and current address; Solicitor to whom articled (for some years / exams); where educated (for some years / exams); examination place. The colonial examination records (LSOC14) are unique in including correspondence and photographs of some candidates, although by no means for every candidate.

A series of Examination questions from 1910 to 1986 in series LSOC 1 provides very useful supplementary material, giving a useful insight in to the development of the curriculum.

The collection is an invaluable source for tracing the education and training of individual solicitors from the mid nineteenth century onwards. It also provides a very detailed record of both the candidates studying for the Law Society's examinations and the wider cultural and social context in which they worked and studied. The detailed catalogue is available on the IALS website at http://ials.sas.ac.uk/library/archives/lsoc.htm.

\section{Additional sources}

IALS also holds a number of significant collections which contain useful supplementary sources for legal biographers: in addition to providing supplementary references to individuals, these collections also provide invaluable contextual background information on matters of legal education and policy development, and should not be overlooked.

\section{The Council Of Legal Education (1845 - 1997)}

In addition to the Bar Examination results, the extensive archives of the Council Of Legal Education, in particular those of the various committees, are a significant 
research resource. It should also be noted that the earliest records in the collection pre-date the examination results, and provide a valuable insight in to the development of legal education and professional standards.

The committee records, in particular those of the Legal Education Committee (CLE 1 \& 2) and the Committee on Examinations (CLE 13) contain numerous references to individuals, both students and officials, and many of the volumes include integral subject and name indexes. Appeals against examination marks, requests for exemptions or postponements of examinations, sometimes including details of personal circumstances may be found in these volumes and also in the Exemptions Cases Books (CLE 20). The committee records also include records of prizes and other awards.

The CLE Calendars (series CLE 15) also provide useful individual information. These printed volumes date from 1901 to 1992 (with a few exceptions) and in addition to providing contextual information such as term and exam dates, also contain list of students and examinations passed.

For full catalogue details, see http://ials.sas.ac.uk/library/archives/cle.htm

\section{Society of Legal Scholars (SLS) 1909 to date}

The archive of The Society of Legal Scholars (SLS) - formerly The Society of Public Teachers of Law (SPTL), dating from 1909 to the present day, is another rich resource for the legal biographer. The detailed archive catalogue can be seen at: http://ials.sas.ac.uk/library/archives/docs/SPTL SLS updated archives handlist 20 13.pdf.

Directories and list of members in series SPTL 6 and 7, dating back to the origins of the Society will enable researchers to trace the memberships and professional progress of individuals; the papers of well known members, relating to their roles as society officials are also included eg Professors Twining and Read, and the records of Annual General Meetings, committee meetings, annual conferences and legal policy consultation papers will also be useful for the legal biographer in tracing members' academic and professional activities.

Fiona Cownie and Ray Cocks' excellent and comprehensive history of the Society ${ }^{1}$, which has made extensive use of the SPTL archive, also provides a very useful research tool and contains many references to individuals who were active in the society.

\section{Other membership organisations}

The RLEA collections include the archives of several smaller membership organisations, which may also be of use in providing information about the professional and academic activities of individuals. These collections include those of The Socio Legal Studies Association (SLSA), The Society of Advanced Legal

\footnotetext{
${ }^{1}$ Cocks, R and Cownie, F (2009) A Great and Noble Profession: The History of The Society of Legal Scholars. Oxford, Hart Publishing, 2009
} 
Scholars (SALS) and the Association of Law Teachers (ALT), all of which will provide evidence of their members' academic and professional activities. The records of the Committee of Heads of University Law Schools (CHULS) are also held at IALS and may also be useful in tracing the professional activities those involved. Detailed catalogues of these collections can be found in the RLEA section of the IALS website.

The archives of the International Law Association (ILA) are also held at IALS, and may be of interest to the legal biographer. Membership records, conference and committee records, and files relating to international braches are included, together with some photographs. The detailed catalogue is available on the IALS website at http://ials.sas.ac.uk/library/archives/ila.htm.

\section{The Bar Council (1883 - 1999)}

The archives of The Bar Council have recently been deposited at IALS, and will shortly be available for research. At the time of writing, the catalogue is in the process of being finalised and will shortly be accessible on the IALS website.

The archive will undoubtedly be of value to the legal biographer: the records range from the establishment of the General Council of the Bar in the late nineteenth century to the late twentieth century and include formal Council and Executive Committee minutes; sub committee minutes, including the Professional Conduct Committee; Annual Reports \& Statements; election registers; subject and correspondence files.

It should be noted that some records appear not to have survived, and there are some significant gaps in a few series, but the archive is nevertheless an extensive and significant addition to the archival resources held at IALS, and which will undoubtedly be widely used.

\section{IALS archives (1946 to date)}

The Institute's own archive is another, often overlooked potential source of information on the careers of individuals who worked there. The Archive traces the history and development of the Institute and its Library from its foundation in 1946 onwards. The professional activities of Institute's staff, including Directors, Librarians, Management and Academic staff, will be reflected in the archive collection, which includes the records of individual Directors and Institute Secretaries relating to their work at IALS (rather than to their whole careers). Directors' papers will be found in series IALS / 2; those of Institute Librarians' can be found in series IALS 3, 4 and 9 and Institute Secretaries' papers in series IALS / 3, 4, 6 and 8. The collection also contains administrative and policy records, including formal committee records, correspondence and files illustrating the development and management of the library; photographs of staff, institute events and premises can also be found in series IALS 12. Full collection details can be found in the catalogue on the archive website at http://ials.sas.ac.uk/library/archives/archives.htm.

\section{Law Librarianship Archives (BIALL, IALL, MOYS) 1970s to date}


In addition its own archive relating to the development and management of the library, the archive holds three collections relating to Law Librarianship which may also provide information on the professional activities of individuals involved in Law Librarianship and Legal Information provision. The International Association of Law Libraries (IALL) archive provides an international perspective. The records of the British and Irish Association of Law Librarians (BIALL) together with the related collection of papers of Betty Moys (MOYS) also provide useful information on the development of the profession and the activities of leading Law Librarians.

\section{Further archival sources}

There are many additional sources beyond IALS which will help your research and which will prove useful in confirming and clarifying biographical details.

The most useful and relevant will be found in other legal archives, of which the most significant are which are the extensive holdings of the archives and libraries of Inns of Court. The Inner Temple Admissions Database which is searchable on line http://www.innertemplearchives.org.uk/index.asp is another particularly useful resource, and will enable researchers to confirm dates of admission and call to the bar. The Law Society maintains its own institutional archive, including committee records, and these may also provide further information about the training and subsequent careers of individuals.

Printed and published material eg Law Lists, Calendars and Directories, many of which are available at the Inns of Court Libraries and Archives, can provide further information: Calendars from 1901 to 1992 can also be found at IALS in archive series CLE / 15 (see above) and Directories of Members can also be found in the records of such organisations as SLS, ILA and other discussed above.

Other essential sources accessible on line include The Times, British Library $19^{\text {th }}$ and early twentieth century newspapers, and the Dictionary of National Biography. The Times in particular is invaluable for tracing Counsels' appearances in court, and the professional activities of Solicitors acting in notable cases.

The Records of early articled clerks, held at the National Archives (see http://www.nationalarchives.gov.uk/records/research-guides/attorneys-

solicitors.htm,) can now be searched on line via the Ancestry website http://search.ancestry.co.uk/search/db.aspx?dbid=2380.

General genealogical sources are sometimes overlooked by researchers, particularly those who have not been involved in tracing their own family histories, but have proved invaluable when tracing the origins and careers of individuals. Many of these sources e.g. the 1841 - 1911 Census returns can be searched via the National Archives website; Parish registers can be searched on line via such sites as the International Genealogical Index https://familysearch.org/ and Scotland's People (see http://www.scotlandspeople.gov.uk/index.aspx), and may give useful contextual information eg. age, address, family, and other household circumstances.

Wills can be particularly informative in providing further contextual details eg assets, bequests to Institutions: they may be found in local record offices; other probate records can be also searched on line via the National Archive website or via the 
Ancestry and Find My Past genealogical websites, and later wills can be seen at the Principal Probate Registry.

\section{Research in the archive collections at IALS}

It is hoped that this article will widen awareness of an important research resource for legal biographers and that readers will be encouraged to visit IALS and explore both the archive and library collections in greater depth. There is a wealth of material to be found. Recent academic researchers have found information on a variety of individuals and subjects, including early women barristers and solicitors; $19^{\text {th }}$ and early $20^{\text {th }}$ century Chinese Bar and Law Society examination candidates; the history of the British lawyers advising on the Japanese legal system; and the examination results of William Heelis, solicitor and husband of the author Beatrix Potter.

You may also find the examination results of many well known figures, including Clement Attlee (CLE 11/6), Helena Normanton (CLE 11/11), and Jawaharlal Nehru (CLE 11/8). Other chance discoveries recently made include the examination results of Henry Charles Dickens and Cedric Charles Dickens, grandsons of Charles Dickens, and sons of Sir Henry Dickens, QC, (in CLE 11/5 and LSOC 9/35 \& 10/36 respectively).

Archive material at IALS can be seen by appointment, under the supervision of the archivist, who works one day per week (currently on Mondays). The archive is available free of charge for personal and academic research, although fees are charged for commercial use.

Detailed catalogues, many of which have already been mentioned, can be found via the IALS archive web page http://ials.sas.ac.uk/library/archives/archive.htm and material catalogued prior to 2006 can also be found by searching the Senate House Library archive database http://archives.ulrls.lon.ac.ukl. The IALS archivist will, of course, be able to provide further advice on using the catalogues and other finding aids during your visit.

Much of the material is in bound volumes or in a fragile condition, and is therefore not suitable for photocopying, but digital non flash photography is permitted, for non commercial purposes, subject to the usual copyright declarations and by permission of the archivist.

For researchers unable to visit the archive in person, The Archivist is able to provide only a limited remote research enquiry service, but is happy to assist where feasible, and to provide further advice. 


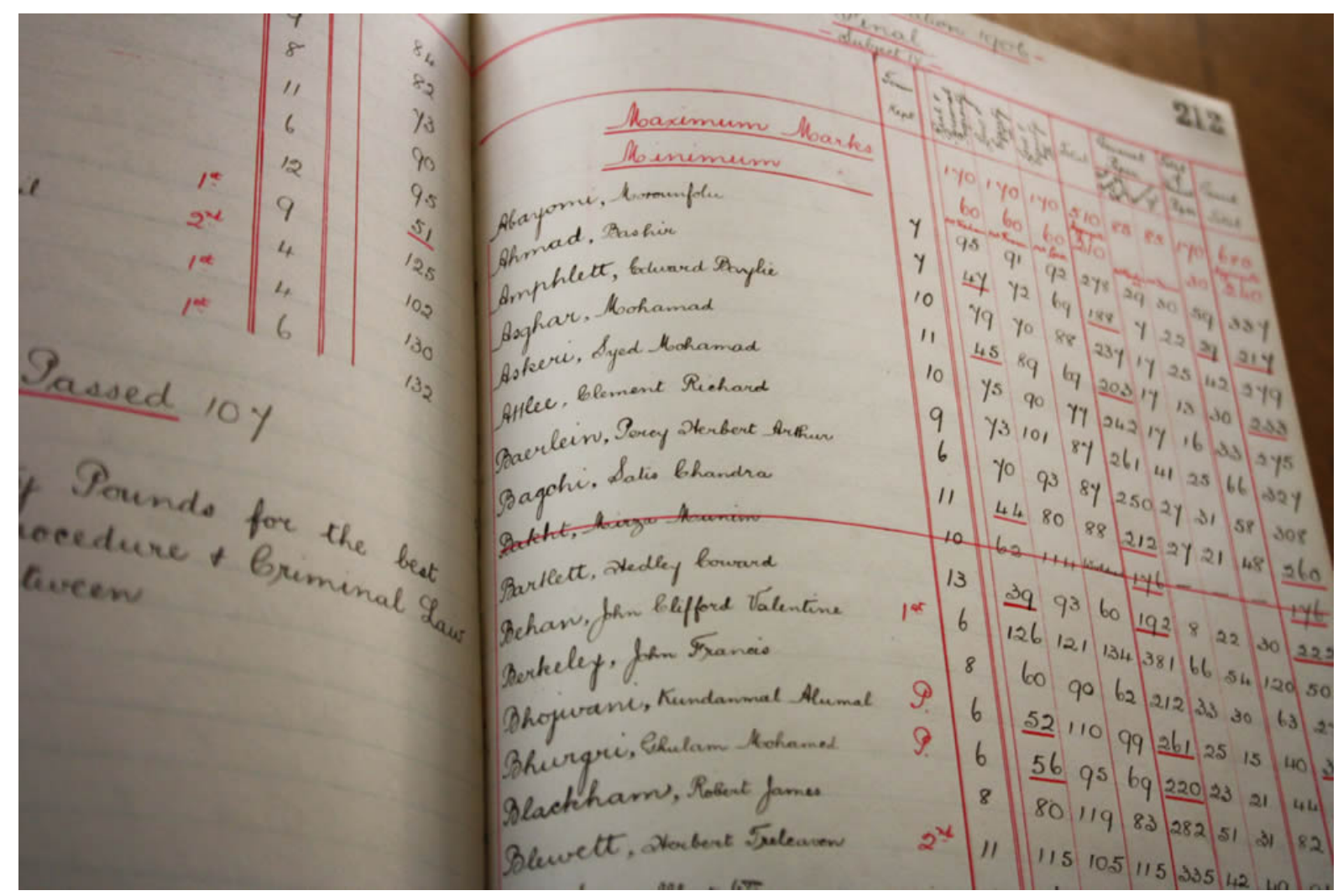

Fig. 1: Examination results of Clement Attlee in Council of Legal Education Archive at IALS (CLE 11/6)

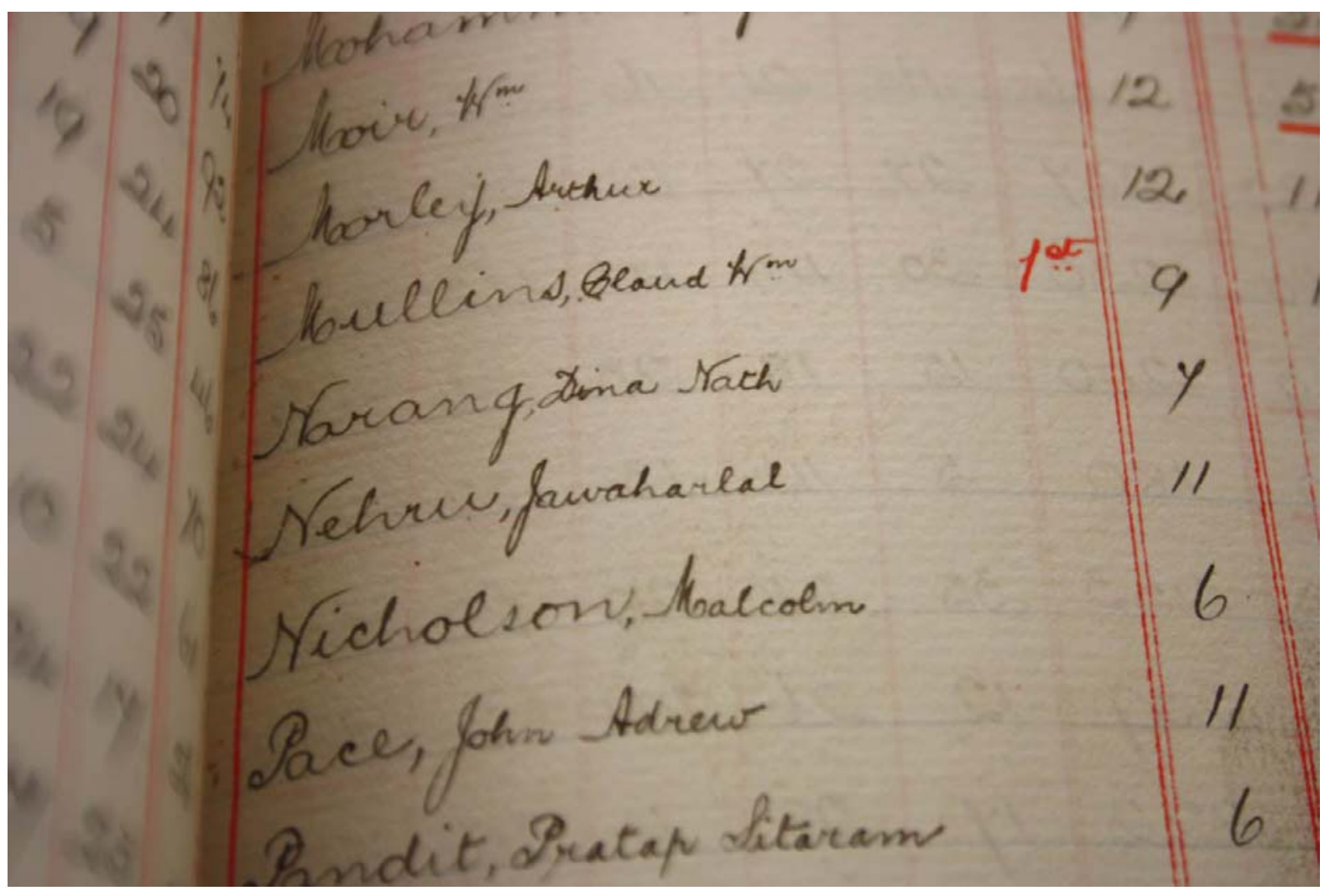

Fig. 2: Examination results of Jawaharlal Nehru in Council of Legal Education Archive at IALS (CLE 11/8) 


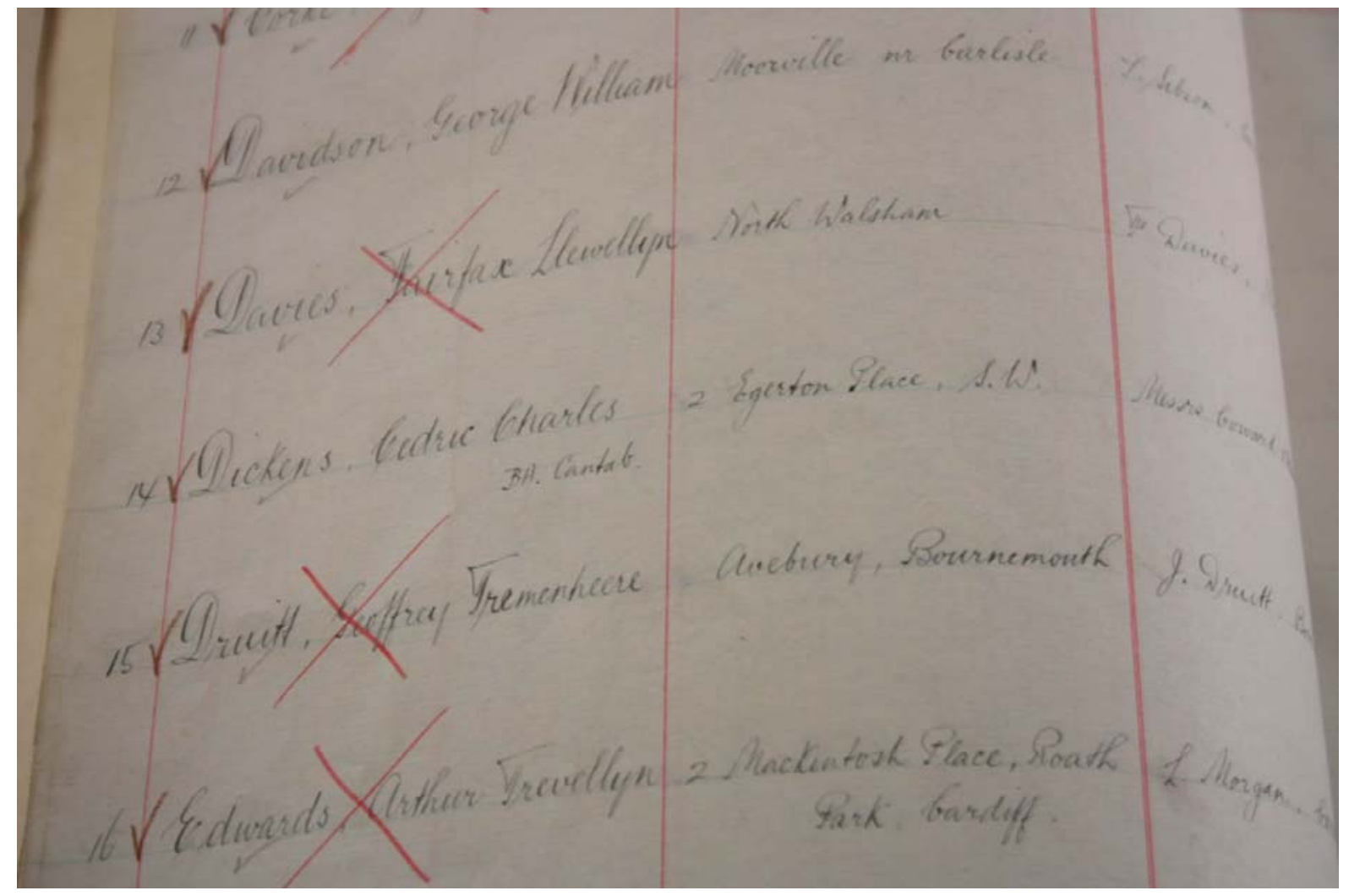

Fig. 3: Examination results of Henry Charles Dickens in Council of Legal Education Archive at IALS (CLE 11/5)

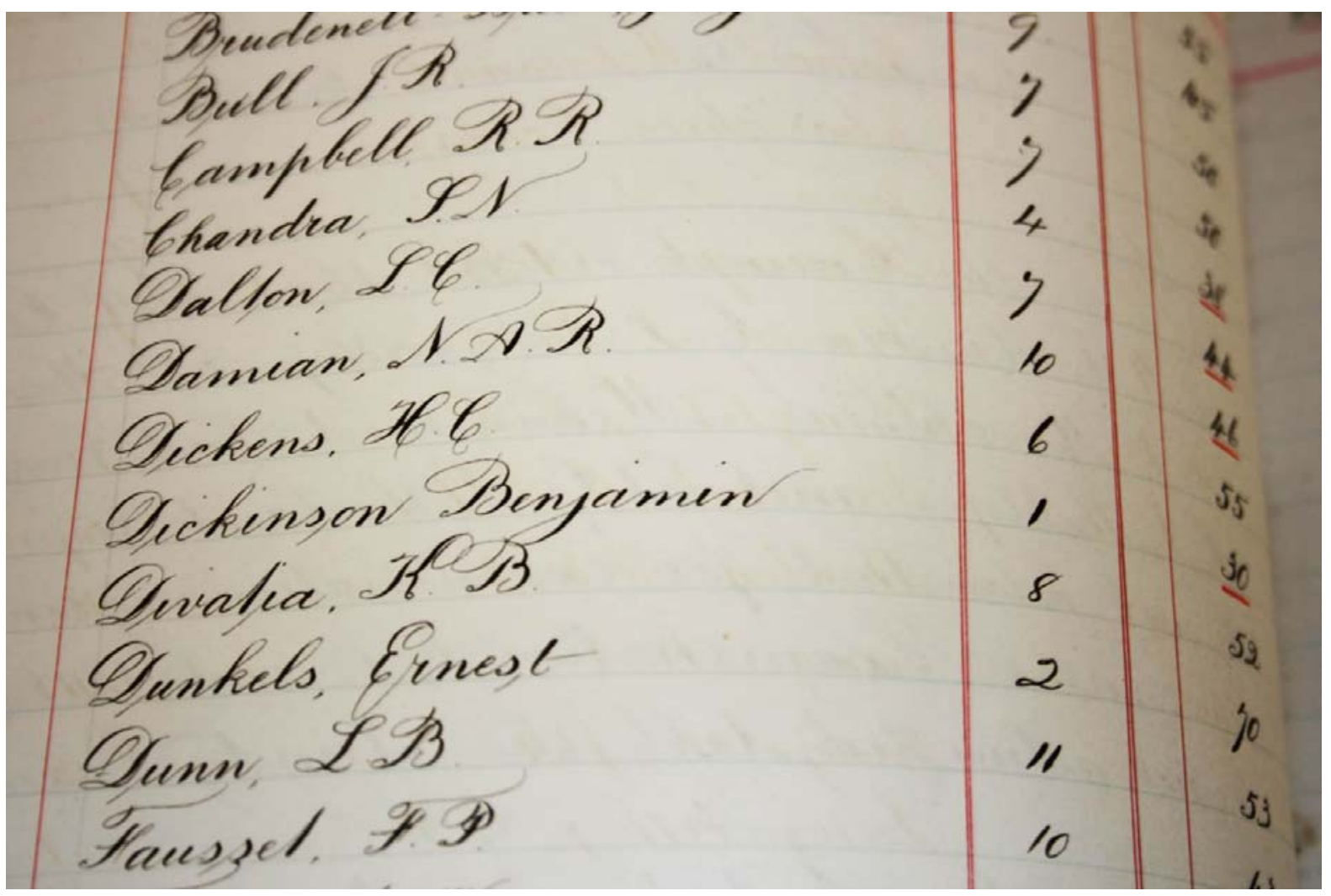

Fig. 4: Examination results of Cedric Charles Dickens in Law Society Examination Results Archive at IALS (LSOC 9/35) 


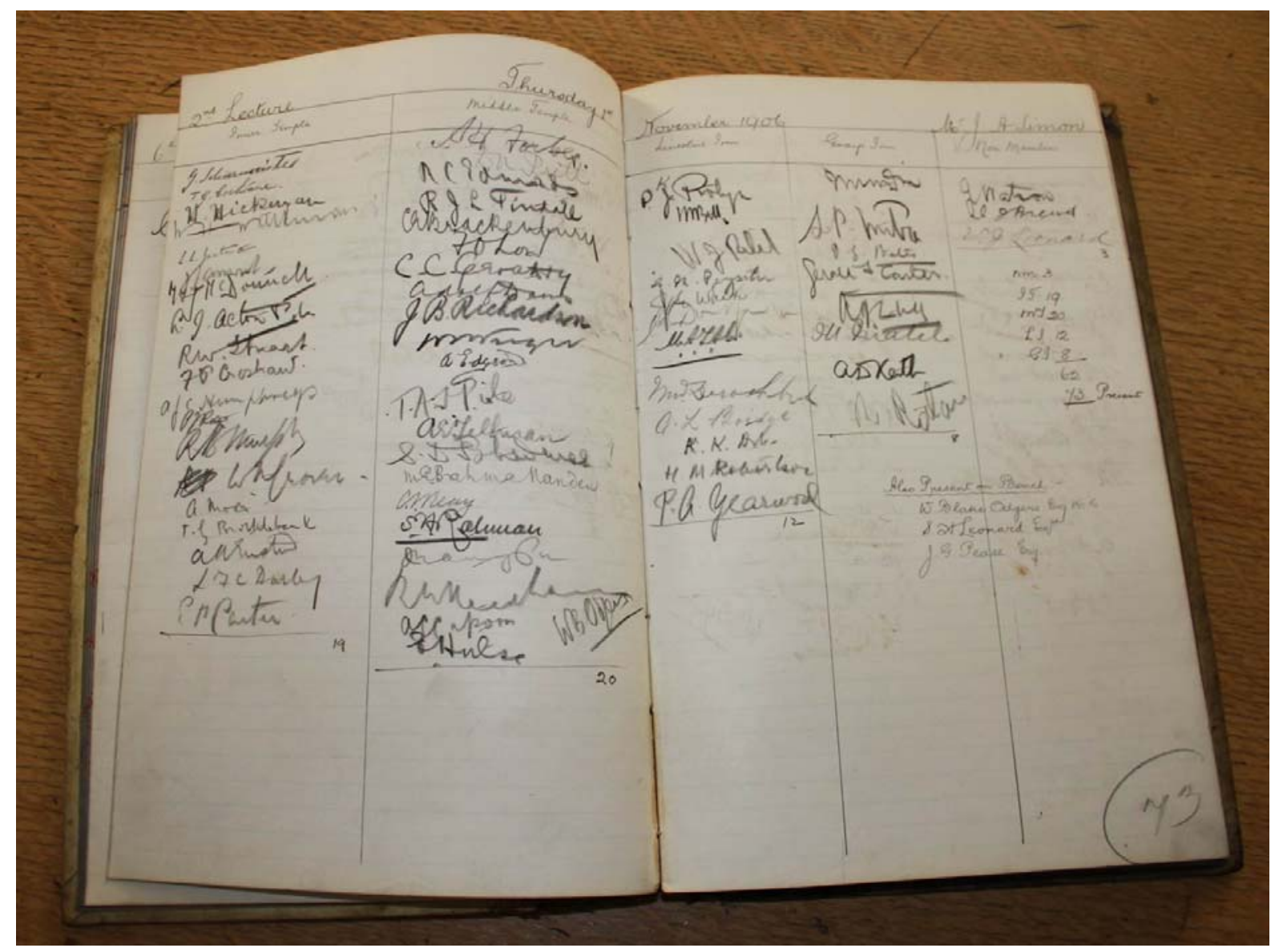

Fig. 5: Signatures in the Register of Evening Lectures in Council of Legal Education Archive at IALS (CLE 17/1) 